\title{
Ultrastructural and Cytochemical Investigation of Asymptomatic Infection by Pythium spp.
}

\author{
Patrice Rey, Nicole Benhamou, and Yves Tirilly
}

First and third authors: Laboratoire de Microbiologie, ESMISAB, Université de Bretagne Occidentale, Technopôle Brest-Iroise, 29280 Plouzané, France; second author: Recherches en Sciences de la vie et de la santé, Pavillon C. E. Marchand, Université Laval, Sainte-Foy, Québec, Canada G1K 7P4.

Accepted for publication 25 November 1997.

\begin{abstract}
Rey, P., Benhamou, N., and Tirilly, Y. 1998. Ultrastructural and cytochemical investigation of asymptomatic infection by Pythium spp. Phytopathology 88:234-244.

The influence exerted by Pythium group F (a minor pathogen ubiquitous in soilless cultures) and $P$. uncinulatum (a nonpathogenic species) colonization on tomato roots was investigated. In both interactions, infected roots did not exhibit obvious symptoms; however, major physiological changes occurred within the host tissues colonized by Pythium group F compared to $P$. uncinulatum. According to our cytological observations, Pythium group $\mathrm{F}$ colonization involved a series of events: first, development and growth of the fungus in the epidermis and outer cortex tissues, which was associated with marked host cell disorganization and even breakdown. In colonized roots, symptoms were not easily discernible because alterations were restricted to the epidermis and outer cortex tissues. Second, pathogen ingress in the inner cortex and stele tissues was associated with massive induction of host defense reactions and alteration of invading hyphae. In a complex interaction that involved

fibrillar materials. P. uncinulatum growth was restricted to the epidermis and outer cortex tissues and associated with relatively minor damage to host cells. $P$. uncinulatum colonization of root tissues did not result in defense events similar to those observed in Pythium group F-infected inner cortex and stele tissues. Moreover, most of the invading P. uncinulatum hyphae were moribund. The results of the current study indicated that symptomless infections can be insignificant in terms of pathology for the plant (i.e., P. uncinulatum) or can be potentially dangerous (i.e., Pythium group F). Our results clearly showed a striking difference between nonpathogenic and minor pathogenic Pythium spp. attacks. The description of the Pythium group $\mathrm{F}$ infection process suggests that this interaction is unique, because the fungus behaves as a necrotrophic fungus in the epidermis and outer cortex tissues, whereas it is a potential inducer of plant defense reactions in the inner cortex and stele tissues. To our knowledge, cytological events similar to those observed with Pythium group $\mathrm{F}$ have not been described until now, even though descriptions of these events could help elucidate several aspects of the relationships between plants and minor pathogens.
\end{abstract} major metabolic changes in root cells, an array of defense-related reactions was produced, as exemplified by the formation of wall appositions and plugging of host cells with osmiophilic, electron-dense, granular, or
Additional keyword: gold cytochemistry.

phenomenon was convincingly shown by Stanghellini and Kronland (33) and Stanghellini and Rasmussen (34) who observed that $P$. dissotocum caused significant yield reductions, even in the absence of visible root and foliar symptoms. However, the situation is not clearly defined, as evidenced by the contradictory results reported in the literature. One of the most cogent examples illustrating such contradictions is the observation that some Pythium spp. isolated from symptomless roots are true saprophytic fungi $(23,24,27)$. Plant pathologists, thus, are confronted with an intriguing problem, and additional research is obviously needed to better define the complex relationship established between some Pythium spp. and their host plants.

Pythium spp. characterized by noninflated sporangia, Pythium group F, have been reported as the most common and ubiquitous Pythium group in a wide range of soils (21), potted plants (35), and soilless cultures $(26,27)$. In addition to molecular investigations (25) and in vitro tests of pathogenicity conducted on Pythium group F $(21,27,35)$, evidence that growth of Pythium group F occurred mainly in the epidermis and cortex of apparently healthy roots of tomato plants grown in hydroponic cultures recently was provided (29). The fungus not only developed at the root surface and produced appressoria-like structures but also colonized the root tissues, ultimately causing yield reduction without inducing visible root symptoms (29). Although of interest, these results have to be viewed with caution, because in the experiments plants were grown under optimal conditions. According to Funck-Jensen and Hockenhull (16) and Chérif et al. (10), Pythium group F dis- 
plays the ability to cause severe necrosis and even root rotting on stressed plants. Thus, it is likely that Pythium group $\mathrm{F}$ is a minor pathogen, as previously defined by Salt (32).

In an attempt to gain further insights into the mechanisms underlying the complex interaction between Pythium group $\mathrm{F}$ and host plants, the current ultrastructural study was undertaken to delineate the cytological events occurring during the infection process. Tomato plants growing without external stresses were inoculated with Pythium group F, and the cytological changes were compared to those induced by $P$. uncinulatum, a species known for its inefficiency in inducing root necrosis on tomato.

\section{MATERIAL AND METHODS}

Plant material. Tomato seeds (cv. Prisca) were surface-sterilized by immersion in $70 \%$ ethanol for 7 min, soaked in $2 \%$ aqueous sodium hypochlorite for $7 \mathrm{~min}$, thoroughly rinsed, and soaked overnight in sterile distilled water. Seeds were sown in peat at a density of three seeds per flat. Plants were grown under greenhouse conditions (natural light during May), with temperatures of $25^{\circ} \mathrm{C}$ during the day and $16^{\circ} \mathrm{C}$ during the night. Eight-week-old plants were inoculated with different Pythium spp.

Fungal strains. Two strains of Pythium group F identified as 317 and 707 were previously isolated from tomato roots growing in soilless cultures (29). In earlier bioassays conducted under hydroponic greenhouse conditions during the 6-month growing season, strain 707 induced higher tomato yield losses than strain 317 . However, despite the ability of the two strains to colonize the root surface, typical root symptoms were not visible (29). Another Pythium group $\mathrm{F}$ strain, identified as strain 11, was provided by $\mathrm{J}$. Hockenhull (The Royal Veterinary and Agricultural University, Copenhagen). This strain was isolated from green pepper roots in a hydroponic system. A pathogenicity test performed by Wulff (39) indicated that Pythium group F strain 11 restricted root elongation and reduced the fresh weight of cucumber plantlets. Root necrosis was not observed. $P$. uncinulatum was isolated from tomato roots grown in soilless culture. In a previous study (P. Rey, unpublished data), P. uncinulatum induced a light yellow coloration on colonized tomato roots. All Pythium strains were grown on V8 agar medium supplemented with $\mathrm{CaCl}_{2}(25 \mathrm{mM})$ for 5 days at $24^{\circ} \mathrm{C}$ in the dark.

Plant inoculation. Plants were inoculated with each Pythium strain by depositing 8 to 10 disks of actively growing mycelium in contact with five main roots per plant. Twelve plants were inoculated with each of the fungal strains studied. Five control plants were not inoculated with the fungus. The experiment was conducted twice.

Tissue processing for electron microscopy. Samples from inoculated and control roots were collected 48, 72, and $96 \mathrm{~h}$ after inoculation and processed for electron microscopy. Root samples were immediately fixed in $3 \%$ (vol/vol) glutaraldehyde in $0.1 \mathrm{M}$

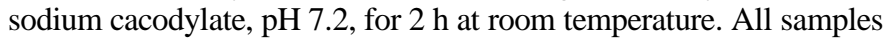
were postfixed for $2 \mathrm{~h}$ in $1 \%$ osmium tetroxide in the same buffer at $4^{\circ} \mathrm{C}$, dehydrated in a graded series of ethanol, and embedded in Epon 812. Root samples were collected randomly from three to four plants for each time period, and the experiment was conducted twice. For each replicate, at least seven samples per plant per time were sectioned.

Thick sections $(1.0 \mu \mathrm{m})$ were cut from the Epon-embedded material with glass knives. Sections were mounted on glass slides and contrasted with basic fuschin-methylene blue. Observations were made under a BH-2 Olympus (Optec, Rungis, France) microscope. For each replicate, at least seven sections per plant per time were observed. Ultrathin sections $(0.1 \mu \mathrm{m})$, collected on Formvarcoated nickel grids, were stained with uranyl acetate and lead citrate before examination with a JEOL (Tokyo) 1200 EX transmission electron microscope at $80 \mathrm{kV}$ or processed for cytochemical labeling.
Preparation of the exoglucanase-gold complex. Exoglucanase, a $\beta$-1,4-D-glucan cellobiohydrolase (EC 3.2.1.21), purified in a fivestep procedure from cellulase produced by Trichoderma harzianum, was used to localize cellulosic $\beta$-1,4-glucans according to a previously described procedure (5).

Colloidal gold suspension, with particles averaging $15 \mathrm{~nm}$ in diameter, was prepared according to Frens (15). The exoglucanase was complexed to gold at $\mathrm{pH}$ 9.0. The gold complex was resuspended in $0.5 \mathrm{ml}$ of phosphate-buffered saline (PBS), $\mathrm{pH}$ 6.0, containing $0.02 \%$ (wt/vol) polyethylene glycol 20,000 (PEG). The complex was stored at $4^{\circ} \mathrm{C}$ until used.

Cytochemical labeling. Ultrathin sections were floated on a drop of PBS-PEG, $\mathrm{pH} \mathrm{6.0,} \mathrm{for} 5 \mathrm{~min}$ and transferred to a drop of the gold complex for $30 \mathrm{~min}$ at room temperature in a moist chamber. The sections were thoroughly washed with PBS, pH 7.2, thoroughly rinsed with distilled water, and stained with uranyl acetate and lead citrate.

Cytochemical controls. Specificity of labeling was assessed using the following controls: (i) incubation of sections with the exoglucanase-gold complex to which $1 \mathrm{mg}$ of $\beta$ - $(1,4)$-D-glucans from barley per ml was previously added; (ii) incubation of sections with the uncomplexed exoglucanase followed by incubation with the gold-complexed exoglucanase; (iii) incubation of the sections with bovine serum albumin gold complex; and (iv) incubation of sections with both stabilized and nonstabilized gold suspension.

\section{RESULTS}

Cytology of infection of tomato root tissues by Pythium group F. Each of the three strains of Pythium group F studied were able to penetrate the root epidermis and develop through most of the inner root tissues, including the cortex, endodermis, paratracheal parenchyma cells, and vascular stele by 48 to $72 \mathrm{~h}$ postinoculation. Fungal invasion correlated with severe host cell damage, preferentially located in the epidermis and outer cortical tissues. Sometimes, a mild yellow coloration was noticed on the infected roots. Each of the three Pythium group F strains induced a similar pattern of fungal invasion, cell alterations, and host reactions.

Hyphae invaded the epidermis by directly penetrating the host cell walls (Fig. 1A, double-headed arrow). A slight host wall distortion occurred, usually when contact was established (Fig. 1A, large arrow). During pathogen ingress in the outer root tissues, penetration of host cell walls by constricted Pythium group F hyphae frequently was observed (Fig. 1B). Penetration channels were narrower than the hyphal diameter, and fungal ingress generally was associated with a slight wall displacement in the direction of fungal growth (Fig. 1B, large arrow). After incubation of sections with the exoglucanase-gold complex, scattered gold particles were deposited over the fibrillar component of the loosely arranged host cell walls at the point of fungal penetration (Fig. 1B, double arrows) but also at a distance from it (Fig. 1B, doubleheaded double arrows).

Within the outer cortical area, fungal invasion coincided with severe host alterations, including organelle disintegration, cytoplasmic aggregation, swelling (Fig. 1C, double arrows), and shredding of host walls. For each strain of Pythium group F, fungal colonization was intense and associated with pronounced alterations of host walls, as illustrated by their marked decrease in electron density (Fig. 1C, arrows) and even their frequent disruption, occasionally leading to tissue maceration (Fig. 1C). Invading hyphae displayed a typical ultrastructure characterized by a dense cytoplasm surrounded by a regular plasma membrane closely appressed against the wall (Fig. 1C and D). One of the most typical reaction features in the invaded outer cortical cells was the coating of some intercellular spaces with a band of electron-opaque material (Fig. 1D, arrows).

Specific host reactions induced when colonized by Pythium group F. Inner cortex 48 to $72 \mathrm{~h}$ after inoculation. Pathogen 


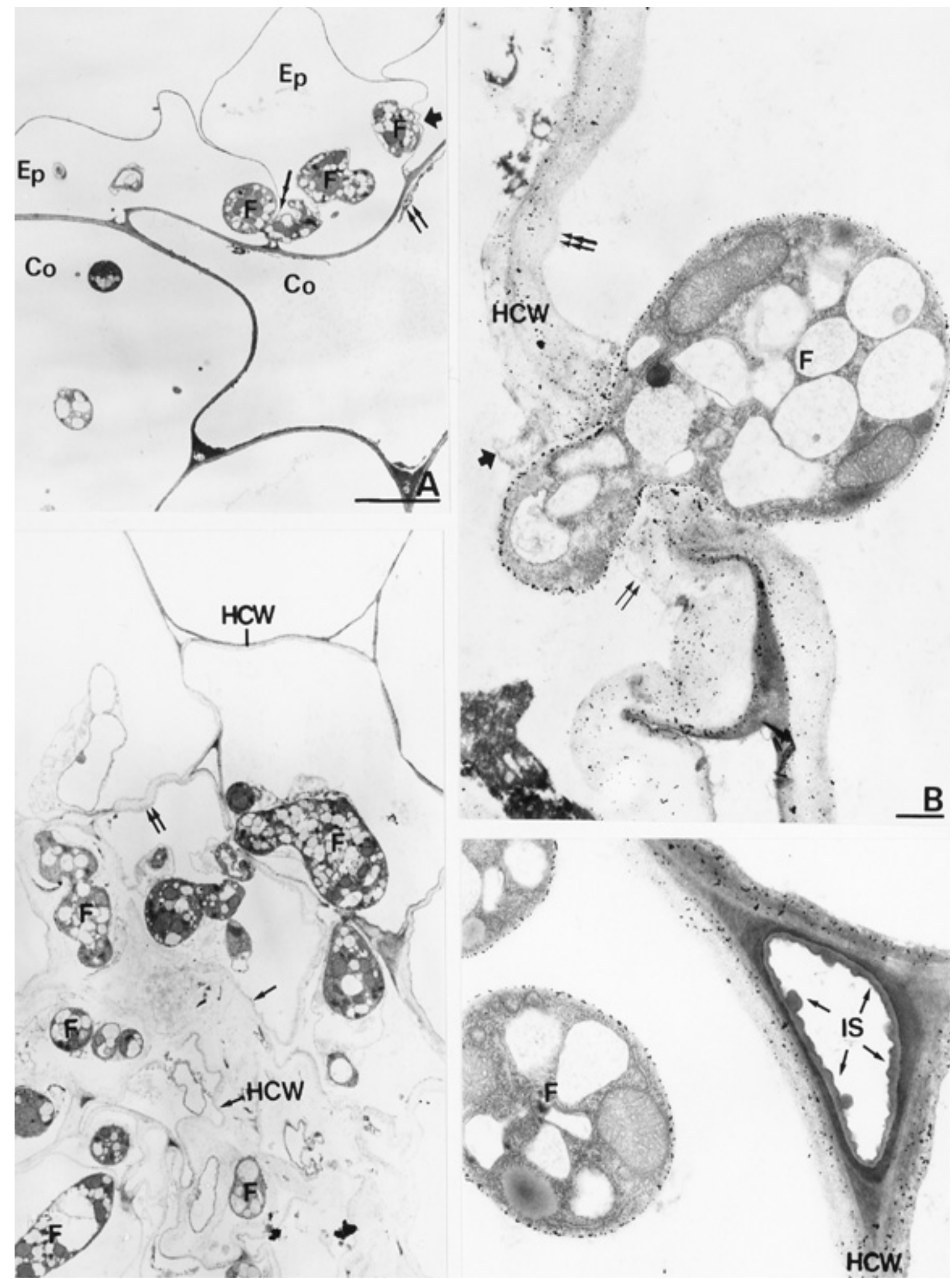

Fig. 1. Transmission electron micrographs of tomato (cv. Prisca) root sections 48 to $72 \mathrm{~h}$ after inoculation with Pythium group $\mathrm{F}$, showing the cytology of infection of the epidermis and outer cortical root tissues. A, Hyphae (F) invade the epidermis (Ep) by directly penetrating the host wall (double-headed arrow). When host and fungal walls interact, a slight distortion occurs over the host wall (large arrow). The cytoplasm aggregates inside a cortical cell $(\mathrm{Co})$ (double arrow). $\mathrm{HCW}=$ host cell wall. $\times 1,500$; bar $=5 \mu \mathrm{m}$. B, Exoglucanase-gold complex labeling. Host wall penetration is achieved by constricted hyphae. The host cell wall is weakly and irregularly (double arrows) labeled even at a distance from the point of fungal penetration (double-headed double arrows). The wall is displaced in the direction of the fungal growth (large arrow). $\times 10,000$; bar $=0.5 \mu \mathrm{m}$. $\mathbf{C}$, Fungal invasion is associated with host wall alterations, such as swelling (double arrows), decreases in electron density (arrows), and disruptions. Structural integrity of the tissue is lost in places. Within the invaded host cells, the cytoplasmic content and organelles are no longer discernible. $\times 2,000$; $\mathrm{bar}=2 \mu \mathrm{m}$. D, Root labeled with the exoglucanase-gold complex, showing the host reaction in the outer cortical tissue 48 to $72 \mathrm{~h}$ after inoculation with Pythium group F. A band of electron-dense material lines the internal wall (arrows) of an uninvaded intercellular space (IS). $\times 12,000 ;$ bar $=0.5 \mu \mathrm{m}$. 
ingress throughout the inner cortical tissue was associated with typical host reactions and frequent fungal cell alterations. One of the major host responses was the accumulation of osmiophilic material that formed large, polymorphic aggregates at the interface between the fungus and host wall. This material accumulated locally and partially surrounded the invading fungal cells (Fig. 2A, large arrows). Encased hyphae showed various degrees of disorganization, ranging from increased vacuolation to marked disorganization of the cytoplasmic content and disruption of organelles such as mitochondria (Fig. 2A, double-headed arrows). After incubation with the exoglucanase-gold complex, uneven labeling occurred over the fungal cell walls (Fig. 2A, double arrows).

Another typical host reaction was the deposition of electrondense inclusions that apparently interacted with the wall of the invading hyphae (Fig. 2B, double arrows). Hyphal distortion was seen frequently (Fig. 2B, arrowheads). Most hyphae surrounded by these dense inclusions exhibited signs of disorganization, as illustrated by the granular aspect of the cytoplasm.

Colonization of the inner cortical root tissue by Pythium $\mathrm{F}$ was associated with the formation of wall appositions close to or directly facing invading hyphae. Hemispherical protuberances resembling papillae were frequently observed at sites of potential fungal penetration (Fig. 2C, large arrows). Attempts to penetrate such wall appositions failed, as evidenced by the presence of highly disorganized penetration pegs (Fig. 2C).

The wall appositions varied in size, shape, and structure: some appeared to be made up of a compact material (Fig. 2C), and others were composed of an underlying amorphous matrix on which were deposited dense, polymorphic inclusions (Fig. 2D). Such papillae were not stratified, but they were bordered by a fine layer of granular substances.

Paratracheal parenchyma 48 to $72 \mathrm{~h}$ after inoculation. In the paratracheal parenchyma area, host cell changes induced in response to fungal invasion were amplified. One of the most noticeable features of host reactions was the formation of hemispherical protuberances or papillae similar to those observed in inner cortical root tissue. Another typical host reaction was the filling of several colonized host cells with fibrillar aggregates that formed a dense network around the fungal wall (Fig. 3A, large arrows). Frequently, fibrillar material was inserted between remnants of organelles and vesicles (Fig. 3B, double-headed arrows). The fibrillar network also was impregnated by an electron-opaque material over a large portion of the host cell (Fig. 3B). Hyphae invading such reacting host cells showed marked alterations, ranging from plasmalemma retraction (Fig. 3A, double-headed double arrows) to wall disruption (Fig. 3B, large arrows) and often release of the cytoplasmic content.

The most striking feature of the host reactions in the paratracheal parenchyma was the occlusion of both colonized and uninvaded host cells (Fig. 4A) with opaque flecks or electron-dense aggregated materials (Fig. 4A, arrows). Hyphae growing in such cells generally were moribund, with extensive disorganization of the preexisting organelles. In spite of such alterations, the thin fungal wall of these disorganized hyphae remained evenly labeled with the exoglucanase-gold complex (Fig. 4B, arrow).

Another reaction observed in the parenchyma cells neighboring the vascular bundles was the impregnation of the host cell walls with an osmiophilic material, as evidenced by their marked increase in electron density (Fig. 4C). This phenomenon was not located only at the meeting point of the fungus with the host wall, as noticed in the inner cortical cells, but also was generalized to the entire wall of the reacting host cells. Released aggregates apparently migrated inside the host cells and frequently surrounded the fungal cells (Fig. 4D, large arrow). Encased hyphae appeared to be empty shells devoid of their protoplasm (Fig. 4D). Alterations of the fungal walls were visible, as illustrated by the weak labeling obtained when treated with the exoglucanase-gold complex (Fig. 4D, double arrows).
Xylem vessels 48 to $72 \mathrm{~h}$ after inoculation. Although Pythium group $\mathrm{F}$ displayed the ability to reach the xylem vessels, the fungal ultrastructure was markedly altered (Fig. 4E). Nearly all invading hyphae were similar to ghost cells in which the cytoplasm and organelles were no longer discernible.

Pythium group F invasion of the vessels was associated with the induction of three host reactions. The first reaction was characterized by deposition of osmiophilic droplets coating the secondary host walls. Moribund invading fungal cells frequently were coated by these aggregates (Fig. 5A, arrows). The second host reaction was the accumulation of bubble-like structures within xylem vessels (Fig. 5B). Frequently, empty hyphae were partially surrounded by these bubbles. Labeling with the exoglucanase-gold complex allowed the labeled fungal wall (Fig. 5B, double arrows) to be distinguished from the unlabeled bubble wall (Fig. 5B, arrows). The third host reaction was the formation of a dense coating that differed from the previous osmiophilic deposit in texture and compactness (Fig. 5C, arrows). This material regularly lined the host secondary wall in addition to forming a thick layer over the wall of invading hyphae (Fig. 5D, large arrow). Incubation with the exoglucanase-gold complex revealed irregular labeling over the coated fungal walls (Fig. 5D, thin arrow).

Cytology of infection of tomato root tissues by $P$. uncinulatum 48 to $72 \mathrm{~h}$ after inoculation. Colonization by $P$. uncinulatum hyphae appeared to be restricted to the epidermal and first outer cortical cell layers. Although close contact between hyphae and host cell walls occurred, host wall alterations were not discernible (Fig. 6A, double-headed arrows). Within the outermost root tissues (epidermis and outer cortex), $P$. uncinulatum induced slight damage that generally was restricted to the invaded host cells. These alterations included disruption of the host cell vacuole and disorganization of the cytoplasmic content (Fig. 6A, arrows).

Invading hyphae $(90 \%)$ were either highly vacuolated or depleted of their protoplasm. In most cases, the regularly labeled fungal wall was the only remaining fungal structure (Fig. 6B, double arrowheads). $P$. uncinulatum-infected roots did not exhibit visible root symptoms.

Host reactions were characterized by the occlusion of intercellular spaces with an electron-dense material (Fig. 6A, double-headed large arrow) and the formation of heterogeneous wall appositions or papillae at sites of attempted fungal entry (Fig. 6B through D).

The papillae also varied greatly in size, shape, and structure, ranging from hemispherical protuberances to multilobed structures (Fig. 6C). Several papillae were surrounded by a compact fibrillar network (Fig. 6D, double arrows). In all cases the papillae appeared impregnated by osmiophilic inclusions. Generally, papillae were surrounded by a dense layer of cytoplasm (Fig. 6B and C).

The occurrence of highly degraded hyphae (Fig. 6B through D), as well as the failure to penetrate the papillae, suggested these newly formed structures were efficient at restricting pathogen ingress toward the inner root tissues.

\section{DISCUSSION}

In recent years, the influence exerted by minor fungal pathogens on plant disease incidence has attracted much attention $(27,29,32)$. Although considerable effort has been directed toward explaining the biological effect of these fungi on plant physiology, only recently has information emerged regarding the sequence of events involved in the infection process $(12,28)$. In light of these studies, it has become more and more apparent that improving our understanding of the highly complex interactions established between minor pathogens such as Pythium group F and their host plants could lead to more rational control of these agents in a number of crops.

The results of the current study demonstrate that infection of tomato plants by Pythium group F elicits a complex plant response in which extensive metabolic changes are induced. These results 

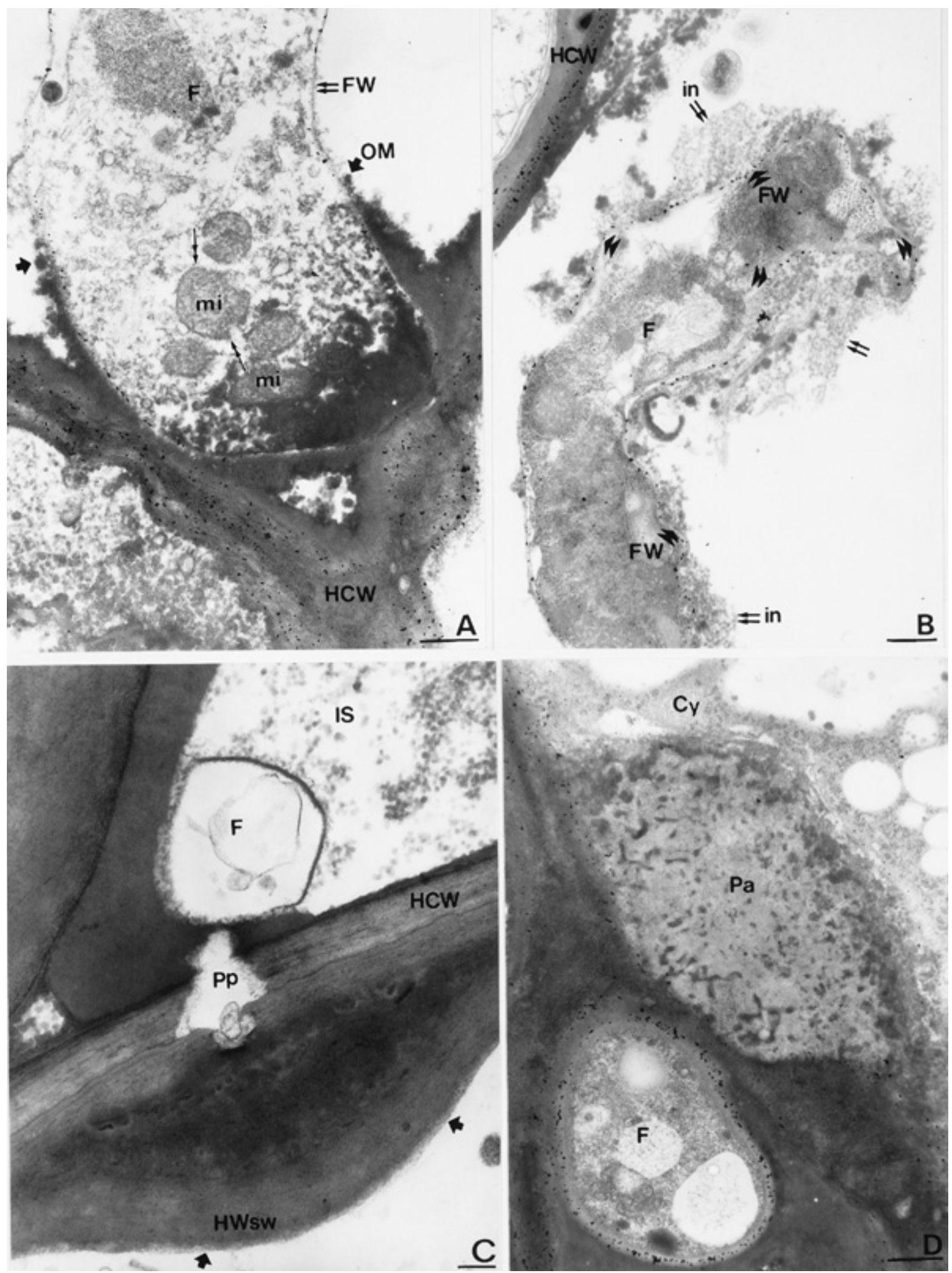

Fig. 2. Transmission electron micrographs of tomato (cv. Prisca) root, showing host reactions in the inner cortical tissue 48 to $72 \mathrm{~h}$ after inoculation with Pythium group F. A and B are labeled with the exoglucanase-gold complex. A, Aggregates of osmiophilic material (OM) (large arrows) partially surround an invading hypha (F). The trapped hypha suffers severe alterations, ranging from cytoplasmic disorganization to disruption of mitochondrial (mi) membranes (double-headed arrows). Labeling is irregular over the fungal wall (FW) (double arrows). HCW $=$ host cell wall. $\times 15,000$; bar $=0.5 \mu \mathrm{m}$. B, Within a colonized host cell, electron-dense inclusions (in) accumulate and interact with one hypha (double arrows). The hypha shows particular fungal wall distortions (double arrowheads). $\times 12,000$; bar $=0.5 \mu \mathrm{m}$. C, The external wall of an invaded intercellular space (IS) displays a marked wall swelling (HWsw) (large arrows) resembling papilla. The empty penetration peg (Pp) of one moribund hypha suggests a failed attempt to penetrate through the wall swelling. $\times 20,000 ;$ bar $=0.2 \mu \mathrm{m}$. D, Exoglucanase-gold complex labeling. A protuberance resembling papilla $(\mathrm{Pa})$ is formed by electron-dense inclusions embedded in an underlined matrix. The papilla is lined by a fine strip of granular substances. The cytoplasmic $(\mathrm{Cy})$ layer surrounds the protuberance. $\times 12,000$; bar $=0.2 \mu \mathrm{m}$. 
are in line with earlier reports on the potential of some Pythium group F strains to colonize root tissues without inducing striking symptoms, such as rotting or necrosis (29), and provide evidence that the interplay between both host and pathogen is a multifaceted process that involves the combination of several mechan- isms, including degradation and defense events. According to our cytological observations, the process of Pythium group F colonization involves a series of events including (i) local penetration by the pathogen into the epidermis; (ii) development and growth of the pathogen in the epidermis and outer cortex, which is asso-
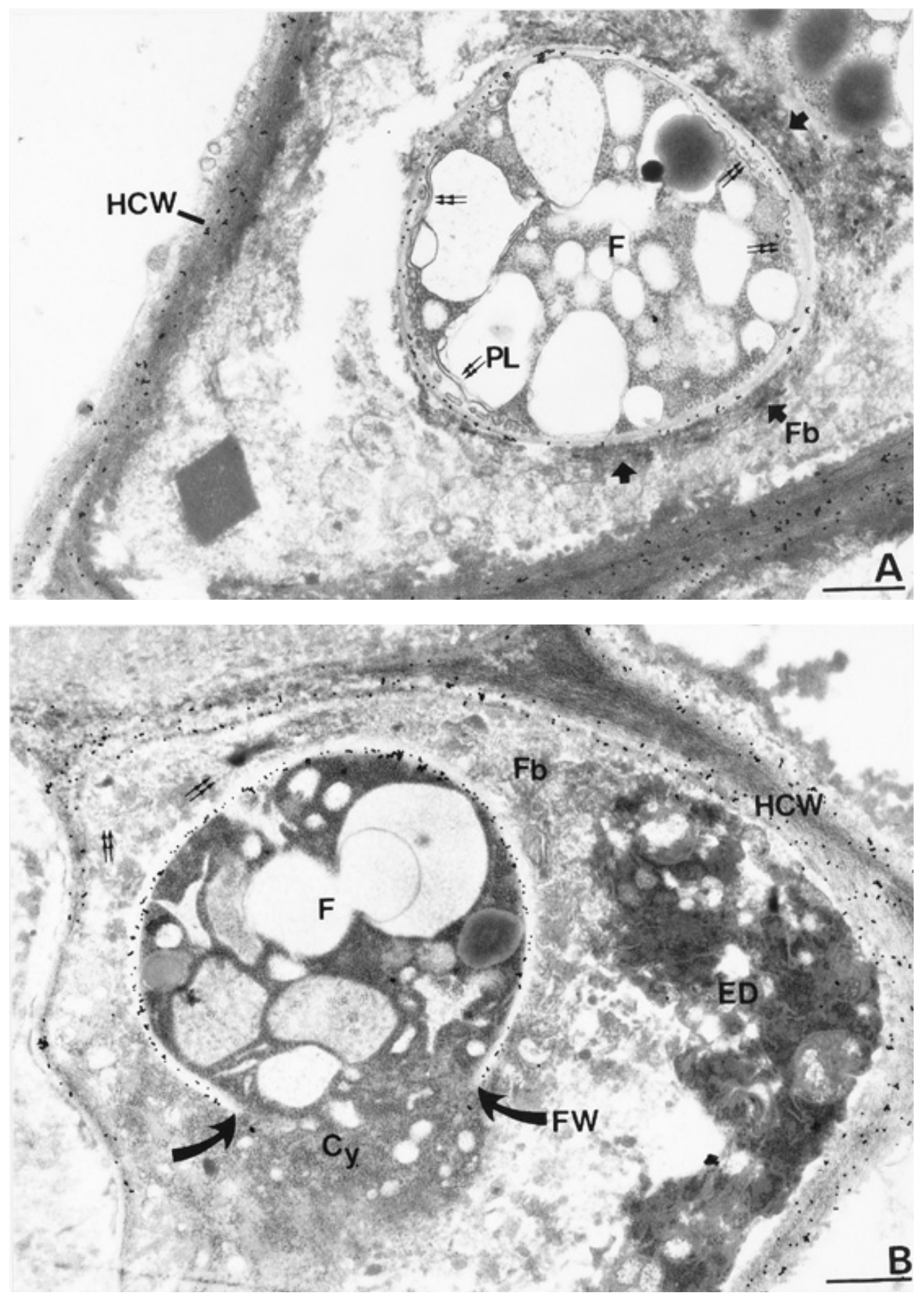

Fig. 3. Transmission electron micrographs of tomato (cv. Prisca) root, showing host reactions in the paratracheal tissues 48 to $72 \mathrm{~h}$ after inoculation with Pythium group F. A and B are labeled with the exoglucanase-gold complex. A, Within a colonized host cell, fibrillar material ( $\mathrm{Fb}$ ) aggregates and forms a dense layer around the wall of a trapped hypha (F, large arrows). The plasmalemma (PL) retracts from the fungal wall (double-headed double arrows), and vesicles accumulate in the paramural space of the invading hypha. $\mathrm{HCW}=$ host cell wall. $\times 15,000$; bar $=0.5 \mu \mathrm{m}$. $\mathbf{B}$, Heterogeneous material constituted by fibrils (Fb), small vesicles (double-headed double arrows), and remnants of organelles surround an invading hypha. A heterogeneous electron-dense material (ED) is located within the same host cell. The hypha cell wall (FW) is disrupted (large arrows), which is accompanied by the release of its cytoplasmic (Cy) content. $\times 15,000$; $\operatorname{bar}=0.5 \mu \mathrm{m}$. 

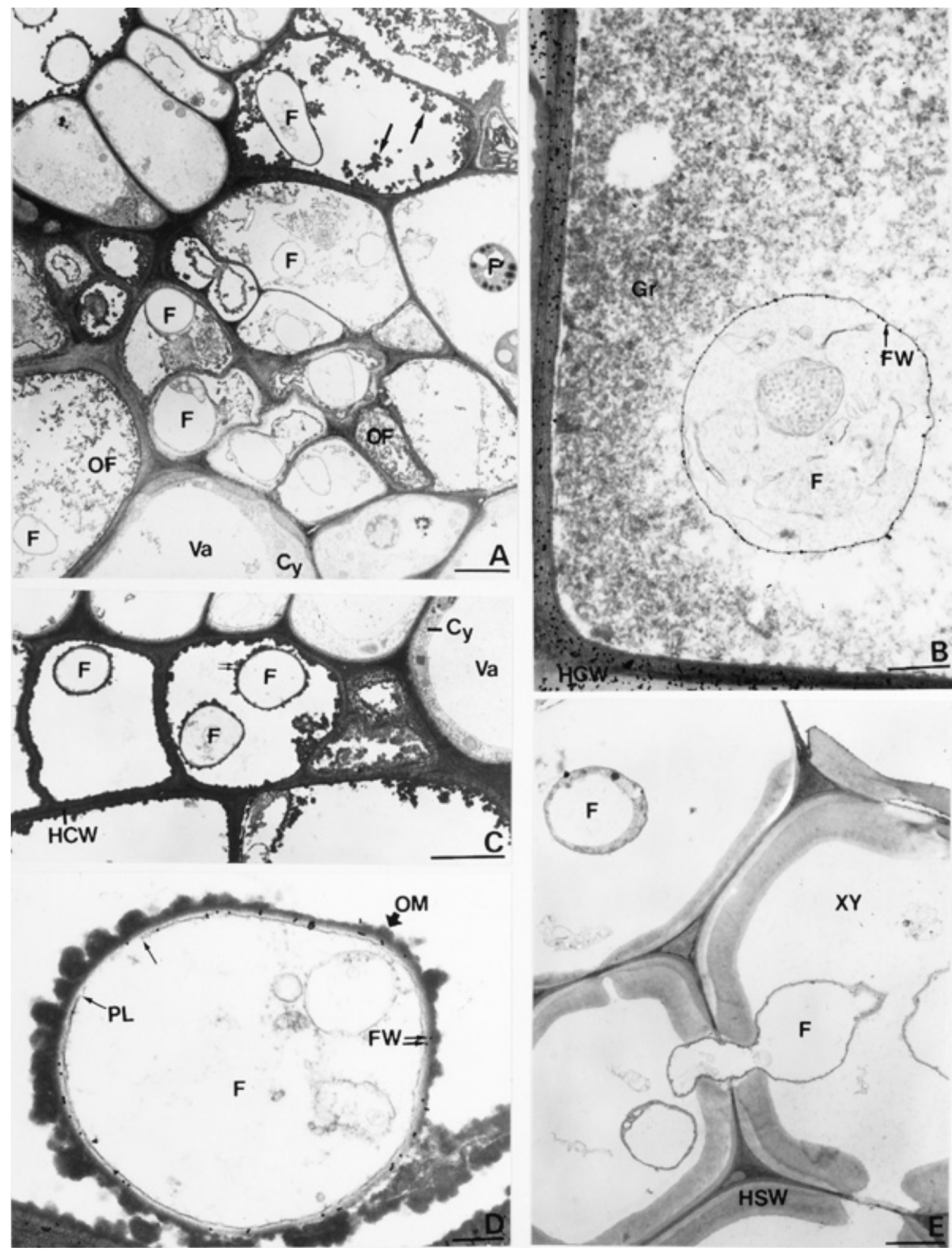

Fig. 4. A through D, Transmission electron micrographs of tomato (cv. Prisca) root, showing host reactions in the paratracheal tissue 48 to $72 \mathrm{~h}$ after inoculation with Pythium group F. A, In the parenchyma vascular (Va) tissue, the occlusion of colonized and uninvaded host cells with opaque flecks (OF) or electron-dense aggregated materials (arrows) is a typical host reaction. Hyphae (F) growing under such environmental conditions are generally highly vacuolated or look like empty shells. $\mathrm{Cy}=$ cytoplasm. $\times 2,500$; bar $=2 \mu \mathrm{m}$. B, Exoglucanase-gold complex labeling. A moribund hypha is growing in a host cell plugged with an electron-dense granular material (Gr). The fungal organelles are disorganized, whereas the thin fungal wall $(\mathrm{FW}$ ) is evenly labeled (arrow). $\times 15,000$; bar $=0.5 \mu \mathrm{m}$. C, Walls of host cells apparently free of organelles and walls of empty hyphae (double arrows) are impregnated with osmiophilic substances. $\times 4,000 ;$ bar $=2 \mu \mathrm{m}$. D, A higher magnification of $\mathbf{C}$ labeled with the exoglucanasegold complex. Aggregates of osmiophilic materials (OM) completely surround the wall of an invading hypha (large arrow). The trapped fungal cell suffers damage, ranging from loss of protoplasm to plasma membrane disruption (arrows). The fungal wall is irregularly labeled (double arrows). $\times 25,000$; bar $=0.2 \mu \mathrm{m}$. E, Transmission electron micrographs of tomato (cv. Prisca) root with colonized xylem vessels 48 to $72 \mathrm{~h}$ after inoculation with Pythium group F. Hyphae are highly vacuolated or depleted of their organelles and are located within the lumen of xylem vessels (XY). An empty hypha has penetrated a host secondary wall (HSW). $\times 4,000 ;$ bar $=2 \mu \mathrm{m}$. 

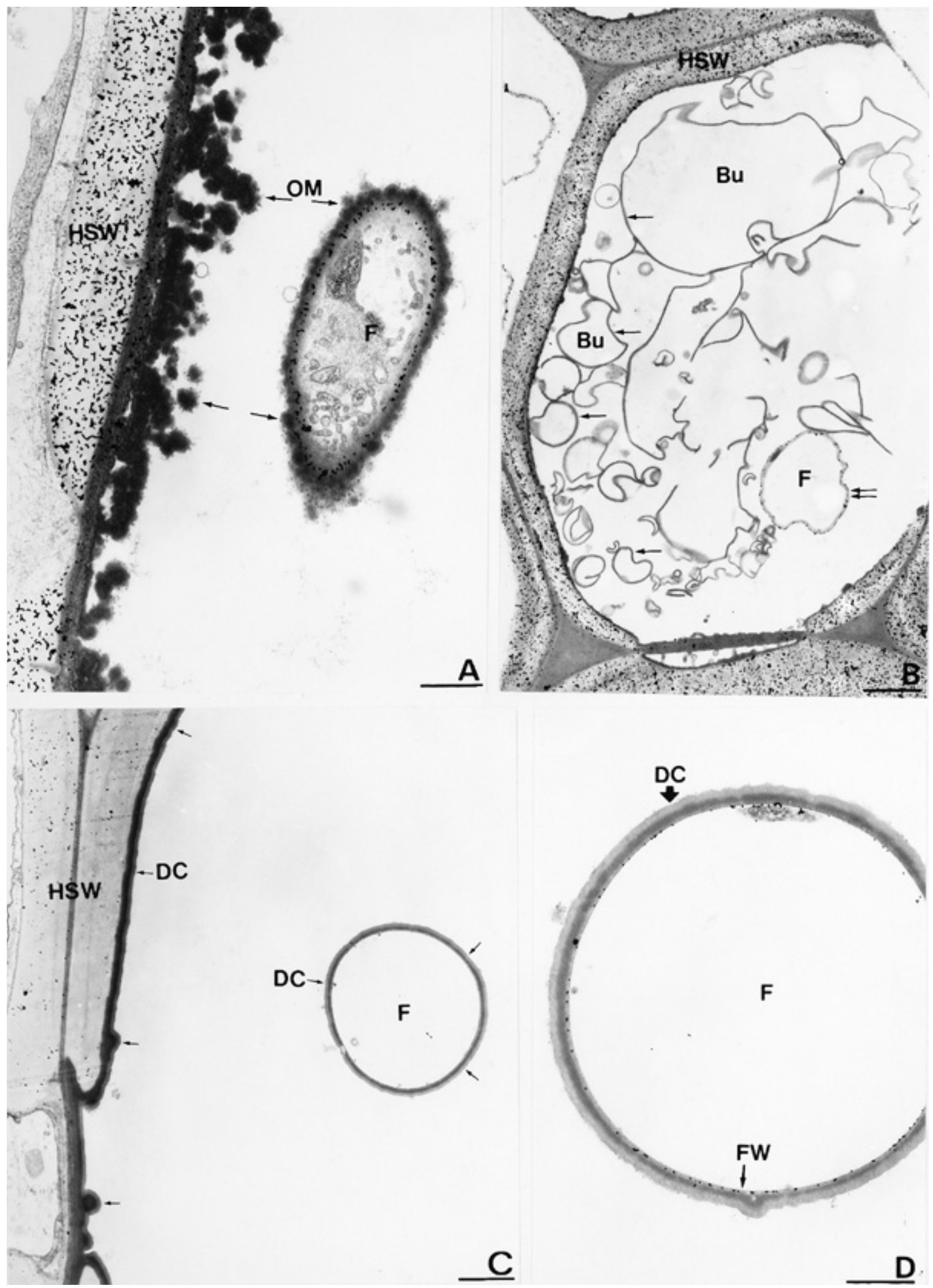

Fig. 5. Transmission electron micrographs of tomato (cv. Prisca) root, showing host reactions in xylem vessels 48 to $72 \mathrm{~h}$ after inoculation with Pythium group F. A through D are labeled with the exoglucanase-gold complex. A, Droplets of osmiophilic material (OM) coat the host secondary wall (HSW) but also migrate toward the lumen of xylem vessels (arrows). Droplets surround the walls of moribund invading hyphae (F). $\times 15,000$; bar $=0.5 \mu \mathrm{m}$. B, An empty fungal cell is partially encased by bubble-like structures $(\mathrm{Bu})$. The hypha wall is regularly labeled (double arrows), whereas the bubble wall is unlabeled (arrows). $\times 6,500 ; \mathrm{bar}=1 \mu \mathrm{m} . \mathbf{C}$, An electron-dense substance (DC) coats the host secondary and fungal walls (arrows). $\times 6,500$; bar $=1 \mu \mathrm{m}$. D, A higher magnification of $\mathbf{C}$. The electron-dense material forms a thick layer over the fungal wall (FW) (large arrow). Only remnants of the cytoplasm together with irregular labeling over the wall (arrow) are seen within the nearly empty hypha. $\times 15,000$; bar $=$ $0.5 \mu \mathrm{m}$. 
ciated with marked host cell disorganization and even breakdown; (iii) pathogen ingress in the inner cortex and stele tissues and massive induction of host defense reactions at sites of potential antagonist entry; and (iv) alteration of the invading hyphae.
Striking differences in the rate and extent of fungal colonization were observed, whether plants were inoculated with $P$. uncinulatum or Pythium group F. Although growth of $P$. uncinulatum was restricted to the outermost root tissues, the three strains of

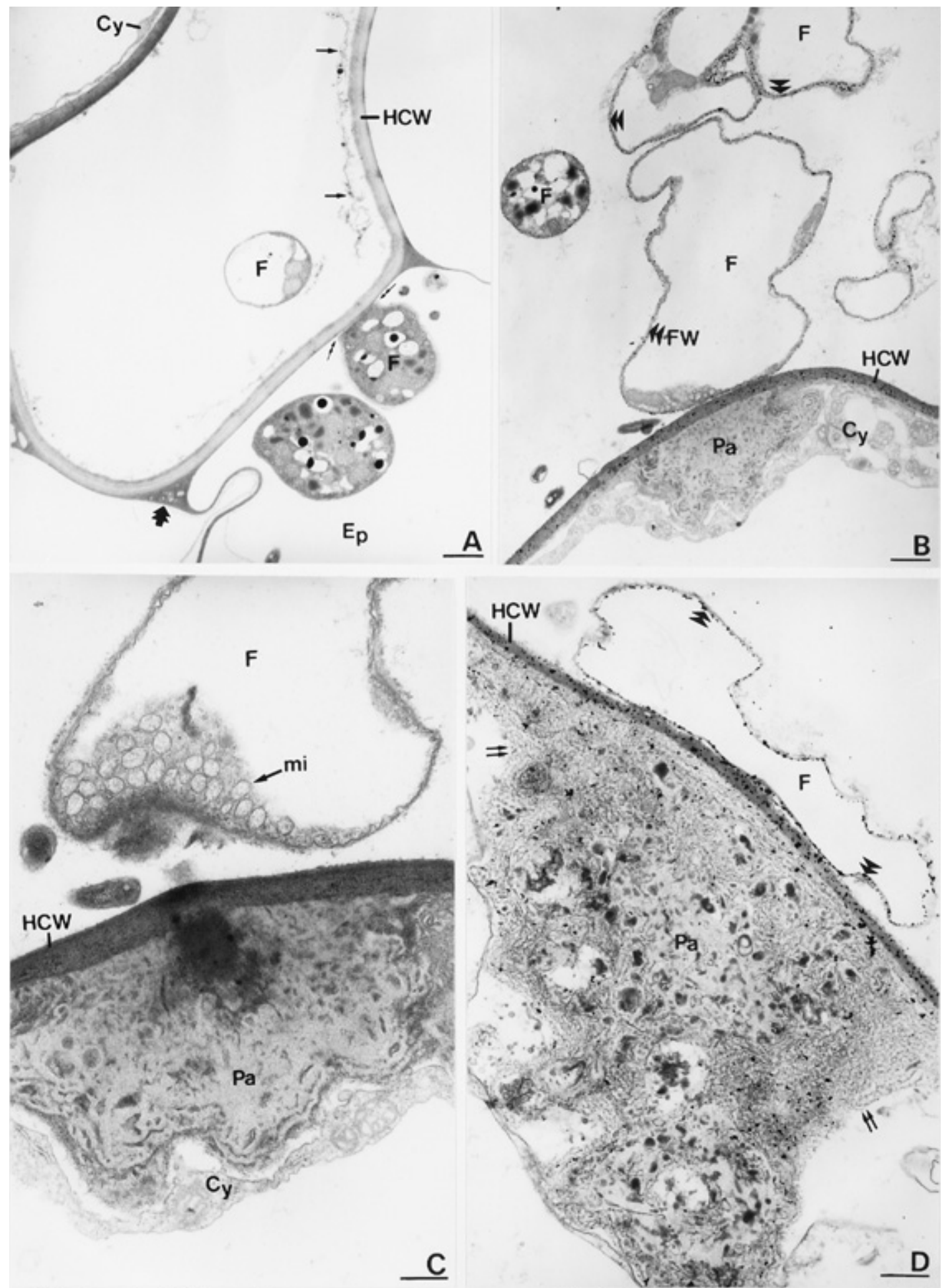

Fig. 6. Transmission electron micrographs of tomato (cv. Prisca) root sections 48 to $72 \mathrm{~h}$ after inoculation with Pythium uncinulatum, showing the cytology of infection and development of host reactions within the colonized epidermis and outer cortical root tissues. B through $\mathbf{D}$ are labeled with the exoglucanase-gold complex. A, Although close contact occurs between hyphae (F) and host cell walls (HCW), the host walls are not damaged (double-headed arrows). The vacuole is disrupted, and there are only remnants of cytoplasm (Cy) within an invaded host cell (arrows). The plugging of intercellular spaces with electrondense substances (double-headed large arrow) is a typical host reaction. Ep $=$ Epidermis. $\times 5,000 ;$ bar $=1 \mu$ m. B, Hyphae frequently face protuberances resembling papillae $(\mathrm{Pa})$. A dense layer of cytoplasm surrounds the papillae. The distorted walls of highly vacuolated hyphae (double arrowheads) are labeled. $\mathrm{FW}=$ fungal wall. $\times 5,000 ;$ bar $=1 \mu \mathrm{m}$. C, A highly vacuolated hypha faces a multilobed papilla. Dense inclusions embedded within a clear matrix are seen in the papilla. There are numerous mitochondria (mi) within the moribund fungal cell (arrow). $\times 12,000$; bar $=0.5 \mu \mathrm{m}$. D, A heterogeneous papilla of an amorphic, clear matrix on which electron-dense inclusions are deposited is formed at a site of potential fungal entry. There is a fibrillar network (double arrows) surrounding the papilla. The wall of the empty hypha is regularly labeled with the exoglucanase-gold complex (double arrowheads). $\times 12,000 ;$ bar $=0.5 \mu \mathrm{m}$. 
Pythium group F studied displayed the ability to parasitize all root tissues without inducing extensive cell damage (except for the epidermis and outer cortex), as occurs in several host-Pythium spp. interactions $(8,13,28)$. In this context, the elaboration of host reactions in the inner cortex and stele tissues of Pythium group Finfected plants and the structural alteration of the invading hyphae shown by the frequent occurrence of empty fungal cells in these tissues was new. Although the process by which a plant operates to fend off invasion by a pathogen in the inner cortex and stele tissues is still misunderstood, Pythium group $\mathrm{F}$, unlike $P$. uncinulatum, clearly displays the ability to colonize from the cortex and reach the vascular stele. This implies that cell wall hydrolytic enzymes, such as pectinases and cellulases, are produced to locally weaken or loosen the host cell walls, facilitating spread into root tissues. The altered pattern of cellulose distribution over the walls of invaded epidermal and cortical host cells confirmed that, indeed, cell wall-degrading enzymes were abundantly produced and even diffused at a distance from the point of fungal contact. This situation is in obvious contrast to that reported to occur with the minor pathogen Colletotrichum coccodes, which induced slight wall alterations in the channel of fungal penetration (12).

More intriguing is the apparent preservation of the structural integrity of the inner tissues in spite of pathogen colonization. Whether such preservation correlates with the strengthening of the host cell walls by structural and chemical barriers or corresponds to a decrease in cell wall-degrading enzyme production remains to be fully elucidated. Considering the specific relationship established between Pythium group F and root tissues, one may be tempted to postulate that this interaction is unique, because, to our knowledge, cytological events similar to those observed with Pythium group $\mathrm{F}$ have not been described previously. The situation is particularly complex: on the one hand, Pythium group F behaves as a necrotrophic fungi in the outer root tissues, and on the other hand, it is a potential inducer of plant defense reactions in the inner root tissues. The induction of host metabolic changes has never been reported to occur to such an extent in plants infected by pathogenic Pythium spp. such as P. ultimum (8) or $P$. aphanidermatum (28).

Cellular changes characterized by the deposition of heterogeneous wall appositions on the inner cell wall surface were typical features of reactions in the inner cortex and paratracheal parenchyma. This phenomenon was even amplified by the impregnation of osmiophilic substances in the host cell walls of reacting root cells. The massive deposition of such structures at sites of attempted fungal entry as well as the accumulation of osmiophilic deposits suggest that inner root cells are signaled to mobilize a number of defense strategies to halt the spread of the pathogen toward the vascular stele. Perivascular responses, associated with papilla formation, have long been reported to be involved in plant resistance to vascular wilt pathogens $(2,3,37)$. According to the texture of the appositions, one may suggest that these newly formed structures are made of a polysaccharide matrix on which other compounds, such as phenolics, are deposited sequentially, probably to build a more impervious barrier.

Another striking feature of the host response was the substantial accumulation of amorphous deposits in the lumen of reacting host cells and in most invaded intercellular spaces. According to its texture and electron density, this aggregated material likely corresponds to phenolic compounds, especially phenols containing $O$ dihydroxy groups, which are known to readily interact with osmium tetroxide $\left(\mathrm{OsO}_{4}\right)$ and to be highly opaque under an electron microscope $(3,4,9)$. Although it is difficult to precisely determine from the current data the extent of the role played by the aggregated material in preventing Pythium group $\mathrm{F}$ invasion and altering the fungal structure, it may be involved in at least two key biological functions. First, its impregnation of the host cell walls and wall appositions may enhance the mechanical strength of these defensive barriers, in addition to protecting them from the del- eterious effect of hydrolytic enzymes. Second, its accumulation at strategic sites (i.e., intercellular spaces) (6) may cause inhibition of fungal growth, as indicated by the distorted and degenerative aspect of fungal hyphae trapped or coated by this opaque material.

Colonization of tomato root tissues by $P$. uncinulatum did not result in defense events similar to those observed in the tomato root-Pythium group $\mathrm{F}$ interaction. Fungal growth was restricted to the outer root tissues, and damage to the host cell walls was reduced, as shown by the regular labeling of cellulose. More intriguing, however, was the presence of moribund hyphae within invaded host cells. Whether the occurrence of empty hyphae was due to the production of host defense molecules or correlated with a specific behavior of $P$. uncinulatum in planta deserves a more indepth investigation.

In spite of major advances in our understanding of plant-minor pathogen relationships, a number of aspects remain open to speculation. For instance, is the alteration of the outer root tissues by Pythium group $\mathrm{F}$ responsible for the observed reduction in plant growth and yield? In complex interactions involving major metabolic changes in planta, the initiation of defense-related reactions in the inner root tissues is a key process in controlling fungal development. One may assume that abiotic factors or factors that may impair plant physiology and consequently the elaboration of plant defense mechanisms are potentially dangerous for the plant. Salt (32) reported that minor pathogen infections are particularly severe during periods of cultural or physiological stress, because plant defenses can be weakened to such an extent that they make the spread of hyphae throughout the inner root tissues easier. In line with this assumption, it was recently reported that plants inoculated with Pythium group F strain 707 were symptomless under hydroponic greenhouse conditions with optimal plant growth (29), whereas plants exhibited severe root necrosis under stressed cultural conditions (10). Although not investigated by Chérif et al. (10), it was suggested that host resistance mechanisms were not effective in limiting fungal colonization within weakened and stressed plants. Therefore, promotion of excellent plant growth conditions is an absolute prerequisite to afford increased plant resistance against infections by minor pathogens such as Pythium group F.

In conclusion, the current study demonstrates that plant-minor pathogen interactions are more complex than was initially thought. Symptomless infections can be insignificant in terms of pathology for the plant (i.e., P. uncinulatum) or can be potentially dangerous (i.e., Pythium group F). It would be interesting to investigate whether biological control (i.e., antagonists or elicitors of plant resistance) may help in controlling such minor infections.

\section{ACKNOWLEDGMENTS}

Financial support for this research was provided by the Brittany Regional Council, the GIS-LBIO Program (ONIFLHOR), and The Natural Sciences and Engineering Research Council of Canada. We thank S. Noël for excellent technical assistance.

\section{LITERATURE CITED}

1. Abad, Z. G., Shew, H. D., and Lucas, L. T. 1994. Characterization and pathogenicity of Pythium species isolated from turfgrass with symptoms of root and crown rot in North Carolina. Phytopathology 84:913-921.

2. Beckman, C. H. 1987. The Nature of Wilt Diseases of Plants. The American Phytopathological Society, St. Paul, MN.

3. Benhamou, N. 1995. Ultrastructural and cytochemical aspects of the response of eggplant parenchyma cells in direct contact with Verticilliuminfected xylem vessels. Physiol. Mol. Plant Pathol. 46:321-338.

4. Benhamou, N. 1995. Elicitor-induced resistance in tomato plants against fungal pathogens: Ultrastructure and cytochemistry of the induced response. Scanning Microsc. 9:861-880.

5. Benhamou, N., Chamberland, H., Ouellette, G. B., and Pauzé, F. J. 1987. Ultrastructural localization of $\beta-(1,4)$-D-glucans in two pathogenic fungi and in their host tissues by means of an exoglucanase-gold complex. Can. J. Microbiol. 33:405-417.

6. Benhamou, N., Chamberland, H., and Pauzé, F. J. 1990. Implication of 
pectic components in cell surface interactions between tomato root cells and Fusarium oxysporum f. sp. radicis-lycopersici. Plant Physiol. 92:9951003.

7. Blancard, D., Rafin, C., Chamont, S., Tirilly Y., and Jailloux F. 1992. Phénomène de perte de racines en culture hors-sol. Rôle des Pythium spp. Pép. Hortic. Mar. Rev. Hortic. 329:35-45.

8. Chérif, M., Benhamou, N., and Bélanger, R. R. 1991. Ultrastructural and cytochemical studies of fungal development and host reactions in cucumber plants infected by Pythium ultimum. Physiol. Mol. Plant Pathol. 39:353-375.

9. Chérif, M., Benhamou, N., Menzies, J. G., and Bélanger, R. R. 1992. Silicon induced resistance in cucumber plants against Pythium ultimum. Physiol. Mol. Plant Pathol. 41:411-425.

10. Chérif, M., Tirilly, Y., and Bélanger, R. R. 1997. Effect of oxygen concentration on plant growth, lipidperoxidation, and receptivity of tomato roots to Pythium F under hydroponic conditions. Eur. J. Plant Pathol. 103:255-264.

11. Cother, E. J., and Gilbert, R. L. 1993. Comparative pathogenicity of Pythium species associated with poor seedling establishment in southern Australia. Plant Pathol. 42:151-157.

12. Delon, R. 1975. Etude ultrastructurale et cytochimique de racines de tomate (Lycopersicon esculentum var. Marmande) parasitées par Colletotrichum coccodes (Wallr. Hughes). J. Phytopathol. 84:322-342.

13. Endo, R. M., and Colt, W. M. 1974. Anatomy, cytology and physiology of infection by Pythium. Proc. Am. Phytopathol. Soc. 1:215-223.

14. Favrin, R. J., Rahe, J. E., and Mauza, B. 1988. Pythium spp. associated with crown rot of cucumbers in British Columbia greenhouses. Plant Dis. 72:683-687.

15. Frens, G. 1973. Controlled nucleation for the regulation of particle size in monodisperse gold solutions. Nat. (Lond.) Phys. Sci. 241:20-22.

16. Funck-Jensen, D., and Hockenhull, J. 1983. The influence of some factors on the severity of Pythium root rot of lettuce in soilless (hydroponic) growing systems. Acta Hortic. 133:129-136.

17. Hodges, C. F., and Coleman, L. W. 1985. Pythium-induced root dysfunction of secondary roots of Agrostis palustris. Plant Dis. 69:336-340.

18. Jenkins, S. F., Jr., and Averre, C. W. 1983. Root diseases of vegetables in hydroponic culture systems in North Carolina greenhouses. Plant Dis. 67: 968-970.

19. Kraft, J. M., Endo, R. M., and Erwin, D. C. 1967. Infection of primary roots of bentgrass by zoospores of Pythium aphanidermatum. Phytopathology 57:86-90.

20. Larsson, M. 1994. Prevalence and pathogenicity of spinach root pathogens of the genus Pythium in Sweden. Plant Pathol. 43:261-268.

21. Linde, C., Kemp, G. H., and Wingfield, M. J. 1994. Pythium irregulare associated with Pinus seedling death on previously cultivated lands. Plant Dis. 78:1002-1005.

22. Martin, F. N. 1995. Pythium. Pages 17-36 in: Eukaryotes, vol. 2. Pergamon Press, Oxford.
23. Mircetich, S. M. 1971. The role of Pythium in feeder roots of diseased and symptomless peach trees and in orchard soils in peach tree decline. Phytopathology 61:357-360.

24. Nyczepir, A. P., and Lewis, S. A. 1984. Incidence of Fusarium and Pythium spp. in peach feeder roots as related to dibromochloropropane application for control of Criconemella xenoplax. Plant Dis. 68:497-499.

25. Rafin, C., Brygoo, Y., and Tirilly, Y. 1995. Restriction analysis of amplified ribosomal DNA of Pythium spp. isolated from soilless culture systems. Mycol. Res. 99:277-281.

26. Rafin, C., Rey, P., and Tirilly, Y. 1995. Comparison of serological and culture plate methods for studying tomato root colonization by a Pythium complex in soilless cultures. Acta Hortic. 382:230-237.

27. Rafin, C., and Tirilly, Y. 1995. Characteristics and pathogenicity of Pythium spp. associated with root rot of tomatoes in soilless culture in Brittany, France. Plant Pathol. 44:779-785.

28. Rey, P., Benhamou, N., and Tirilly, Y. 1996. Ultrastructural and cytochemical studies of cucumber root infected by two Pythium species with different modes of pathogenicity. Physiol. Mol. Plant Pathol. 44:213-231.

29. Rey, P., Nodet, P., and Tirilly, Y. Pythium F induce a minor but ubiquitous disease in tomato soilless cultures. J. Plant Pathol. In press.

30. Robertson, G. I. 1973. Occurrence of Pythium spp. in New Zealand soils, sands, pumices, and peat, and on roots of container-grown plants. N.Z. J. Agric. Res. 16:357-365.

31. Sadik, E. A., Payak, M. M., and Mehta, S. L. 1983. Some biochemical aspects of host-pathogen interactions in Pythium stalk rot of maize: I. Role of toxin, pectolytic and cellulolytic enzymes in pathogenesis. Acta Phytopathol. Acad. Sci. Hung. 18:261-269.

32. Salt, G. A. 1979. The increasing interest in "minor pathogens." Pages 289-312 in: Soilborne Plant Pathogens. Academic Press, New York.

33. Stanghellini, M. E., and Kronland, W. C. 1986. Yield loss in hydroponically grown lettuce attributed to subclinal infection of feeder rootlets by Pythium dissotocum. Plant Dis. 70:1053-1056.

34. Stanghellini, M. E., and Rasmussen, S. L. 1994. Hydroponics, a solution for zoosporic pathogens. Plant Dis. 78:1129-1138.

35. Thinggaard, K., and Middelboe, A. L. 1989. Phytophthora and Pythium in pot plant cultures on an ebb and flow bench with recirculating nutrient solution. J. Phytopathol. 125:343-352.

36. van der Platts-Niterink, A. J. 1981. Monograph of the Genus Pythium. Studies in Mycology. No. 21. Centraalbureau voor Schimmelcultures, Baarn, Netherlands.

37. Walton, J. D. 1994. Deconstructing the cell wall. Plant Physiol. 104: 1113-1118.

38. Waterhouse, G. M. 1968. The genus Pythium Pringsheim. Mycol. Pap. 110:1-71.

39. Wulff, E. 1996. Studies of mycoparasitic and plant Pythium spp.: Root colonization, histopathology, growth stimulation and auxin production. M.S. thesis L8963. The Royal Veterinary and Agricultural University, Copenhagen. 